\title{
Two methods of preparing thin sections of wet soil from sediments in a marine intertidal zone in the Oosterschelde (the Netherlands)
}

\section{J. Kooistra}

Visiting research worker of the Netherlands Soil Survey Institute (Stiboka), Wageningen, the Netherlands

Accepted: 28 May 1979

Key words: sediment, thin section, freeze-drying, acetone

\section{Summary}

Two sets of identical thin sections from the most unripened sediments in the intertidal zone were prepared by two methods: replacement of the soil moisture by acetone (Miedema et al., 1974) and freeze-drying (Jongerius \& Heintzberger, 1975). The thin sections prepared by the first method were of a good quality and did not show any artificial cracking. Preparation was very time-consuming and besides salts humic substances were removed. The thin sections prepared by the second method were of a poorer qualitiy, but still satisfactory. They showed artificial cracking. Preparation time was much shorter and only some salts were removed. Preparing thin sections by this method can be improved.

\section{Introduction}

Thin sections of samples from unripened sediments of a recent intertidal zone cannot be prepared by the normal drying procedure. They contain too much water, have a high salt content and burrowing animals are present. In the last decennia a number of methods have been developed to impregnate wet soil samples (see amongst others: Greene-Kelly \& Chapman, 1970; Jongerius \& Heintzberger, 1975; Miedema et al., 1974; Reineck, 1963; Sing, 1969; Stephan, 1969; Tourtelot, 1961). None of these methods was especially tested for not embanked, very unripened marine sediments. So two sets of identical samples were taken of the most unripened sediments in the intertidal zone and prepared by two methods. The thin sections measured $15 \mathrm{~cm} \times 8 \mathrm{~cm}$.

\section{Material}

The most unripened sediments in an intertidal zone are found in fine-grained de- 
M. J. KOOISTRA

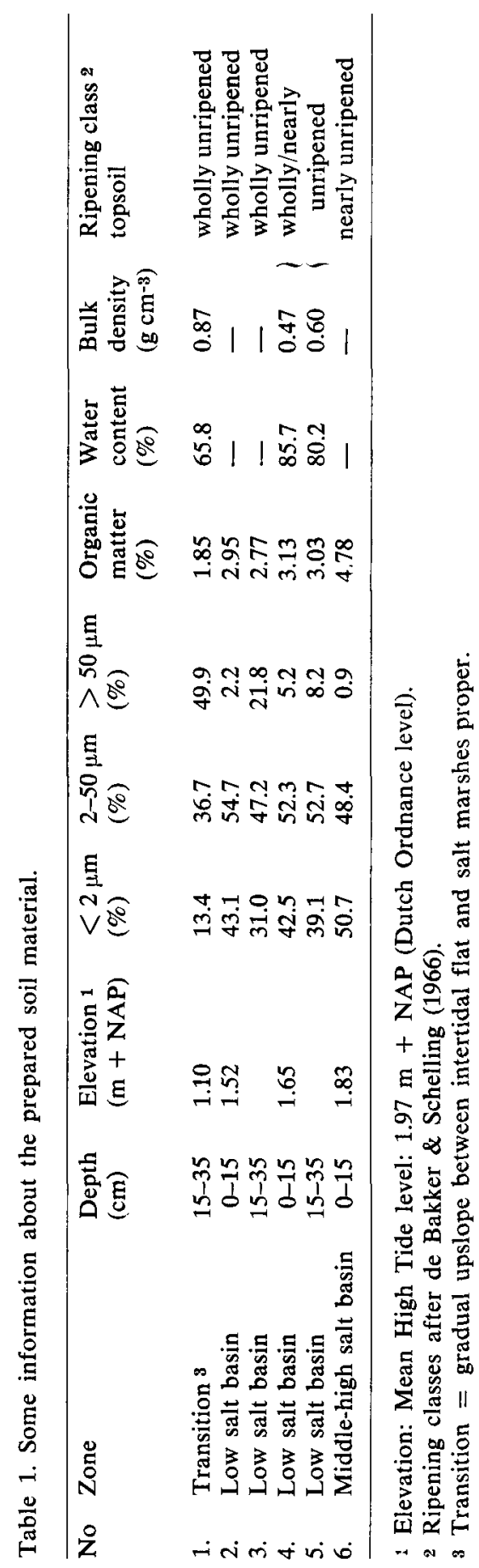


posits situated below Mean High Tide level. These sediments are found (1) in the highest parts of the intertidal flats; (2) in the basins of the salt marshes below Mean High Tide level, and (3) if present, in the gradual transition from intertidal flats to salt marshes. Sediments deposited at higher levels in the intertidal zone, even if they contain higher clay contents, are firmer. They are longer exposed to the air between floods and so soon lose a part of their initial water content (Kooistra, 1978).

In the area of the most unripened sediments two sets of 6 samples were collected. Some information about these samples is given in Table 1 . The clay contents of the samples were very varied. The elemental composition of the clay fraction, determined by X-ray fluorescence was fairly constant. X-ray diffraction showed the presence of smectite, chlorite, illite and kaolinite, as well as of mixed-layer clay minerals of illite with chlorite and/or smectite. Major differences in the clay mineralogical composition were not observed (Kooistra, 1978).

The sediments in the intertidal zone had a high organic matter content, that is positively correlated with the clay content. In recent coastal sediments in the Netherlands usually a linear relation between the amount of clay and organic matter is found (see, amongst others, Zuur, 1958; Verhoeven \& Akkerman, 1967). All samples contained carbonates. Due to the marine environment samples from the topsoils of the basins of the salt marshes beneath Mean High Tide level contained between 1.2 and $3.0 \mathrm{~g}$ salts on $100 \mathrm{~g}$ oven-dry soil.

With the exception of the natural-levee deposits, the water contents in this part of the intertidal zone ranged between 60 and $200 \%$, the bulk densities between 0.35 and $0.90 \mathrm{~g} \mathrm{~cm}^{-3}$ (Kooistra, 1978). Samples No 2 and 4 were derived from the most unripened sediments present in the intertidal zone.

\section{Methods}

According to the way in which the water present in the samples is removed or neutralized, the methods for impregnating wet soil samples can be grouped under four headings: (1) replacement; (2) critical point drying; (3) 'wet' impregnation; (4) freeze-drying (Jongerius \& Heintzberger, 1975). The two methods used here are: replacement of the soil moisture by an organic liquid (Miedema et al., 1974), and freeze-drying (Jongerius \& Heintzberger, 1975).

Preparation of thin sections by the method developed by Miedema et al. (1974) With this method the soil moisture is replaced by acetone and the acetone-saturated sample is impregnated with the unsaturated polyester resin synolyth according to the method of FitzPatrick (1970).

Contrary to the method of Miedema et al., the samples, $5 \mathrm{~cm}$ thick, were placed in individual glass boxes and covered with a heavy glass lid to prevent evaporation. In this way chemical changes could be followed more accurately. Eight times, about once a week, the water/acetone mixture in the glass boxes had to be syphoned off and replaced by pure acetone until no water was detectable in the mixture syphoned off. The first three times a distinct light-coloured precipitation was pre- 
sent on the bottom of the glass boxes, which diminished afterwards. The last two times no precipitation occurred. The liquids of the samples were clear, except for sample 2 and 3 , which were turbid twice before they were syphoned off. The first four times the water/acetone mixtures syphoned off were distinctly coloured. Brown colours were dominant; in other cases they were more greenish or yellow. The last time the mixtures syphoned off were still slightly coloured.

After nine weeks the acetone-saturated samples, including the sample boxes, were impregnated in stainless steel impregnation boxes as described by Miedema et al.

The samples took about three months to harden. For the final hardening the samples were put in a drying oven at temperatures not exceeding $40{ }^{\circ} \mathrm{C}$ for $4-6$ days. After being cooled down in the oven the samples were removed from the impregnation boxes and sawn. Then it appeared that the soil samples were not thoroughly hardened. The sawn blocks were again impregnated with an identical synolyth/acetone mixture. After about six weeks the samples were hard and treated in the same way as before. This time the blocks were hardened thoroughly and thin sections could be prepared in the normal way.

The freeze-drying method as developed by Jongerius \& Heintzberger (1975)

The freeze-drying procedure consists of two steps: the freezing of the sample at $-158{ }^{\circ} \mathrm{C}$ and the drying of the frozen sample via evaporation of ice and sublimation of the ice vapour on an ice condensator.

The freezing of the samples, $2 \mathrm{~cm}$ thick, took three minutes tor each sample; the drying of the frozen samples took about a week. Then the samples were placed in stainless steel boxes and impregnated with the same impregnation material as mentioned in the former method. Also the final hardening was performed in the same way. When the hardened blocks were sawn, only the first sample was thoroughly hard. The other samples were again impregnated in the same way as before. Of the 70 samples from the intertidal zone prepared by the freeze-drying method, in total 15 samples had to be reimpregnated, all derived from the most unrepened part. After the reimpregnation thin sections were prepared as usual without further complications.

\section{Results and discussion}

The thin sections of both methods could be used for micromorphological study. Except for sample No 1, prepared by the replacement method, the thin sections were of a good quality.

The shrinkage in the soil material prepared by the replacement method was of the same order $(5 \%)$ or slightly higher as mentioned by Miedema et al.

Macroscopically, the thin sections prepared by freeze-drying showed some artificial cracking. The thin sections of sample 3,4 and 5 had cracks over nearly the whole surface $(8 \mathrm{~cm} \times 15 \mathrm{~cm})$, the other thin sections only locally. The sizes of the cracks were usually less than $1 \mathrm{~mm}$ wide and several centimeters long, sometimes with bifurcations. These cracks did not cause disturbances in the adjoining soil material or present pedological features. The thin sections prepared by the replace- 
ment method did not show macroscopically any cracks. Microscopically, the thin sections prepared by freeze-drying showed fine artificial cracks, either along the edges or in a central oval. This is the result of warping of the sawn impregnated block. When the sawn surfaces of the warped blocks are ground, the plane surfaces reach into the disturbed central zone of the blocks where fine cracks are found due to ice crystal formation during freezing (Jongerius \& Heintzberger, 1975). The presence of these fine artificial cracks hamper observations on phenomena that show minor changes in composition, packing and orientation of the soil constituents as for example: phenomena due to faunal activities, infilling of soil material in voids and plasmic fabrics. The thin sections prepared by the replacement method did not show small artificial cracks. In these sections phenomena due to faunal activities and infilling of soil material in voids were clearly observable. Plasmic fabrics could be clearly observed. Interpretation, however, had to be done with care as humic substances are removed by repeatedly replacing soil moisture by acetone.

\section{Conclusion}

The thin sections prepared by the replacement method were (except No 1) of good quality and very useful for the study of non-distinctive phenomena. However, during replacement of the soil moisture by acetone humic substances were removed. Here no striation in the plasmic fabrics was found after removing humic material. This fact supported the opinion that the striated fabrics present in polder soils were a result of soil development after reclamation. Preparation of these thin sections was very time-consuming.

The thin sections prepared by freeze-drying were of good quality but gave some problems with the interpretation of non-distinctive phenomena. These are probably due to salts, as thin sections prepared by this method of other parts of the intertidal zone were of a better quality. Therefore the quality of thin sections can be improved if before freezing the soil moisture of the samples is replaced by distilled water. Furthermore, thin sections had to be prepared as quickly as possible after sawing the hardened blocks to prevent warping.

\section{Acknowledgments}

Thin sections were prepared by the replacement method of Miedema et al. (1974) at the Soil Science Institute, State University, Utrecht; thin sections were prepared by the freeze-drying method of Jongerius \& Heintzberger (1975) at the Netherlands Soil Survey Institute, Wageningen.

\section{References}

Bakker, H. de \& J. Schelling, 1966. Systeem van bodemclassificatie voor Nederland. De hogere niveaus. Pudoc, Wageningen.

FitzPatrick, E. A., 1970. A technique for the preparation of large thin sections of soils and unconsolidated materials. In: Micromorphological techniques and applications. Harpenden, Technical Monograph No 2. 
Greene-Kelly, R. \& S. Chapman, 1970. The preparation of thin sections of soils using polyethylene glycols. In: Micromorphological techniques and applications. Harpenden, Technical Monograph No 2.

Jongerius, A. \& G. Heintzberger, 1975. Method in soil micromorphology. A technique for the preparation of large thin sections. Soil Survey Pap. No 10. Soil Survey Institute, Wageningen.

Miedema, R., Th. Pape \& G. J. van de Waal, 1974. A method to impregnate wet soil samples, producing high quality thin sections. Neth. J. agric. Sci. 22: 37-39.

Kooistra, M. J., 1978. Soil development in recent marine sediments of the intertidal zone in the Oosterschelde - The Netherlands. A soil micromorphological approach. Soil Survey Pap. No 14. Soil Survey Institute, Wageningen.

Reineck, H. E., 1963. Nasshärtung von ungestörten Bodenproben im Format $5 \times 5 \mathrm{~cm}$ für projizierbare Dickschliffe. Senckenberg Lethea 44: 357-362.

Singh, R. B., 1969. A versatile method for treatment of clay soils for thin-section fabric studies. J. Soil Sci. 20: 269-273.

Stephan, S., 1969. Gefriertrocknung und andere bei der Herstellung von Bodendünnschliffen benutzbare Trocknungsverfahren. Z. PflErnähr., Düng., Bodenk. 123: 131-140.

Tourtelot, H. A., 1961. Thin sections of clay and shale. J. Sediment Petrol 31: 131-132.

Verhoeven, B. \& T. J. Akkerman, 1967. Buitendijkse mariene gronden, hun opbouw, bedijking en ontginning. With summary: Marine foreland, its formation, embankment and reclamation. Van Zee tot Land, No 45. Tjeenk Willink, Zwolle.

Zuur, A. J., 1958. Bodemkunde der Nederlandse bedijkingen en droogmakerijen. Deel C. Het watergehalte, de indroging en enkele samenhangende processen. Directie van de Rijksdienst voor de IJsselmeerpolders, Kampen. 